\title{
The Devils of Due Process in Criminal Detection, Detention, and Trial
}

\author{
Roger J. Traynor
}

We recall on this occasion not only Justice Cardozo's surpassingly noble spirit and imaginative genius, but his concern that judicial decisions evince a reasoned consideration of their far-reaching consequences. We can pay no better tribute to his sense of professional responsibility than to consider together the far-reaching consequences of judicial decisions in our own day on the now crucial problems of criminal procedure.

Lawyers as well as laymen often voice extreme views on the problem of crime in the catch phrases of the day, and today's vogue is to pitch them at courts. A giant problem is in no measure solved, however, by indiscriminate charges that the courts have a predilection either for coddling criminals or for depriving those suspected of crime of whatever due process is due them. We might better concern ourselves with reinforcing the words of Mr. Justice Clark: "There is no war between the Constitution and common sense."1

Certainly there need be no war. It could break out at any time, however, unless we succeed in bringing constitutional doctrines down to earth on the homely local scenes. That may prove even more of a challenge than the launching of such doctrines, for landings often call for more skill than takeoffs.

It is no secret that we have had some spectacular takeoffs in recent years. Our concern with pretrial criminal procedure has correspondingly grown in the time span encompassing the $M c N a b b-M a l l o r y^{2}$ doctrine on limiting prearraignment interrogation to foster prompt arraignment, the $M a p p^{3}$ decision extending to states the rule excluding evidence obtained from unconstitutional searches and seizures, and the

Roger J. Traynor, Chief Justice, The Supreme Court of California, received an A.B. degree in 1923 and Ph.D. and J.D. degrees in 1927 from the University of California. This article was presented as the twenty-third annual Benjamin N. Cardozo lecture at a meeting of the Association of the Bar of the City of New York on April 19, 1966.

1 Mapp v. Ohio, 367 U.S. 643, 657 (1961).

2 McNabb v. United States, 318 U.S. 332 (1943); Mallory v. United States, 354 U.S. 449 (1957).

3 Mapp v. Ohio, 367 U.S. 643 (1961). 
recent constellation of cases that includes the limelighted Escobedo ${ }^{4}$ case extending the right to counsel to the pretrial stage.

Amid the vociferous and often irresponsible castigation of courts for their zealous watch on due process, we do well to remember what a void the United States Supreme Court's rules have filled. The fault lies with the public, and particularly the legal profession, that constitutional rules have so long remained the major script of criminal procedure. In a wilderness all too little regulated by statutes the Court has been compelled to formulate such rules out of cases that have come before it at random. Now at long last these rules are bestirring legal groups to tackle long needed revision of criminal procedure on a comprehensive basis. Thus the American Bar Association has embarked on a thoroughgoing survey of the whole field ${ }^{5}$ and the American Law Institute has recently completed a tentative draft of a Model Code of Pre-Arraignment Procedure. ${ }^{6}$ Such projects, together with the Criminal Justice Act of 1964, ${ }^{7}$ may well give an impetus to state legislation. We can welcome such projects even while regretting their tardiness, but we know they may take a long time to mature or even to materialize. Meanwhile, it is urgent that we stabilize our course for the duration.

Such studies are better late than never, but there is still a penalty for long neglect. We now confront a long interim of living with the present conglomeration of federal and state rules, a devil's brew that is brewing wildly. Moreover, we must somehow find rational ways of applying constitutional rules of olympian tenor to varied and ever changing local scenes, where even law enforcement officers range from the scrupulously lawful to the soddenly lawless. The best of them are likely to grow impatient with recurring messages that loom to them, rightly or wrongly, as outlandish. Nothing is more unnerving to those amid the flak on the front lines than to receive commands of constitutional force phrased in unmistakably unclear language. In their view the courts are throwing the books at them, books that strike them of a weight either confoundedly heavy enough to leave them lightheaded or confoundedly light enough to leave them heavyhearted. It is difficult to determine the nature and extent of their wounds, but from the outcry there is no doubt about their pain and suffering.

As for the United States Supreme Court, it too encounters frustra-

4 Escobedo v. Illinois, 378 U.S. 478 (1964); Massiah v. United States, 377 U.S. 201 (1964); White v. Maryland, 373 U.S. 59 (1963); Hamilton v. Alabama, 368 U.S. 52 (1961).

5 See Lafave, Arrest: The Decision To Take a Suspect into Custody (1965); Newman, Conviction: The Determination of GuIlt or InNocence Wrthout Trial (1966). Three other books are in preparation.

6 Alr Model Code of Pre-Arratgnment Procedure (Tent. Draft No. 1, 1966).

7 I8 U.S.C. $\S 3006 \mathrm{~A}$ (1964). 
tions whenever it goes beyond its relatively simple task as monitor of the federal administration of criminal justice. When federal criminal procedure is at issue it can formulate appropriate rules of nonconstitutional reach. ${ }^{8}$ It has no comparable flexibility, however, in dealing with cases involving state criminal procedure; then its only recourse is to beam forth messages with constitutional radiations.

The sympathetic who hope that those on the front lines will get well from their bouts with the books and that the supreme wordspinners will get better, often overlook the third market for sympathy where huddle the middlemen who must establish a working pax in bello between the pacific skywriters and the bellowing front lines. It falls regularly to the state judges and recurringly to federal judges to expound with common as well as constitutional sense the skywriting that at times dots just enough t's to cross the eyes, but trails off on the if's, and's, and but's. The loftier the message and the more removed from the local scene, the more difficult it is for the judges on the ground to work out the ground rules. If they fail to transpose the message into earthy language, either because of their own ineptitude or because the message itself defies transposition, it continues to plane in the stratosphere with ill effect to itself as well as to those who are grounded. A rugged constitution, by definition the law of the land, suffers a loss of vitality when it must circle in thin air indefinitely.

Such circling is sometimes envisaged in terms reflecting the experimental temper of an age in which even the scribes of advertising describe their efforts as running something up a flagpole to see who salutes it. Presumably they can promptly run it down again if there are no salutes. In contrast, when the United States Supreme Court runs up a message, we are all bound to give it our respects, so that at first thought it hardly seems of experimental character. There are times, however, when no one has any clear idea of what respects we are supposed to give. An intriguing conjecture has gained currency that the Court has no clear idea either, but that it wisely awaits a variety of responses from the landlocked, which it can then ponder at leisure with a view to amplifying or contracting the import of its original message. ${ }^{9}$ It does not specify at the outset what responses will be valid, so the conjecture goes, because it thereby impels courts in every

8 E.g., the $M C N a b b-M a l l o r y$ rule, based on the Court's supervisory power, is not binding on the states. Stein v. New York, 346 U.S. 156, 187 (1953); Gallegos v. Nebraska, 342 U.S. 55, 63-65, 73 (1951); Brown v. Allen, 344 U.S. 443, 476 (1953); Townsend v. Burke, 334 U.S. 736, 738 (1948) (dictum). See also Culombe v. Connecticut, 367 U.S. 568, 600-01 (1961) (opinion of Frankfurter, J.).

9 Cf. Bickel, Curbing the Union, in Poumtics and the Warren Court 146 (1965). 
region to think their way out of the ensuing problems and thus to serve as experimental stations of constitutional hypotheses. It is then free to confirm or reject, in the best interests of the nation, local interpretations of its language.

There is some poetic justice in compelling state courts to resolve in more than provincial terms the problem of policing the community without oppressiveness. Had all state courts taken the initiative in that regard there would have been less need for the United States Supreme Court to become involved in policing the police. There might have been little need at all, had state legislatures undertaken to formulate modern standards of police procedure, or had all police departments undertaken to raise their own standards. The cases that were fought all the way to Washington brought us slowly to the realization that the Court was moved to act, for better or worse, faute de mieux.10

We know how circumspectly, sometimes all too circumspectly, it has moved in some areas. Thus it took over thirty years, from 1932 to 1963, to develop the right to counsel at the trial and on appeal. Subsequent to Powell $v$. Alabama ${ }^{11}$ and Johnson $v$. Zerbst ${ }^{12}$ there came the limiting Betts v. Brady ${ }^{13}$ rule in 1942, on which the Court marked time with eroding exceptions ${ }^{14}$ before overruling it at last in Gideon v. Wainwright $t^{15}$ and extending the right to counsel to appeals in Douglas v. California. ${ }^{16}$

The Court also made haste slowly, though with more reason, to extend to the states the rule excluding evidence obtained by unconstitutional searches and seizures. ${ }^{17}$ It is a rule of enough basic worth to merit our characterizing it as the bon petit diable of due process in criminal detection. The states had abundant notice that it was on the way. In a critique of Mapp $v$. Ohio, I noted:

By 1961, roughly half of the states had adopted the exclusionary rule, with local variations. There was no uniformity of interpretation, however, and less than consistency in either the federal or state gloss of the rule. There emanated from the federal cases a sensitivity to federal-state relations that

\footnotetext{
10 See Griswold, The Long View, 51 A.B.A.J. 1017 (1965).

11287 U.S. 45 (1932).

12304 U.S. 458 (1938).

13316 U.S. 455 (1942).

14 See Israel, Gideon v. Wainwright: The "Art" of Overruling, 1963 Sup. Cr. REv. 211, 251-61; Kamisar, Book Review, 78 HARv. L. Rev. 478, 481-82 (1964).

15372 U.S. 335 (1963).

16372 U.S. 353 (1963).

17 See Allen, Federalism and the Fourth Amendment: $A$ Requiem for Wolf, 1961 Sur. CT. REv. 1.
} 
goes far to explain the willingness of the United States Supreme Court to afford the states ample time and latitude to determine how to enforce the right it had announced in Wolf v. Colorado in 1949. However guarded the Court was about state remedies, it left no doubt that the right was of constitutional dimension, for "Security of one's privacy against arbitrary intrusion by the police-which is at the core of the Fourth Amendment-is basic to a free society. It is therefore implicit in 'the concept of ordered liberty' and as such enforceable against the States through the Due Process Clause."

It was quickly apparent that this otherwise eloquent declaration went limp on the key word enforceable. In many states there had not yet loomed any effective remedies to attend the right that loomed so large. Wearing its rich constitutional cloak, it went begging for recognition. Alone of the princely rights it often went begging in vain. It became a classic right without a remedy. In California six years elapsed between Wolf v. Colorado and People v. Cahan, and all during that time we were painfully aware of the right begging in our midst. We remained mindful of the cogent reasons for the admission of illegally obtained evidence and clung to the fragile hope that the very brazenness of lawless police methods would bring on effective deterrents other than the exclusionary rule. Accordingly we were proceeding with caution before responding to the message in Wolf $v$. Colorado, to the long and short of the handwriting on the distant wall. We needed no more than Irvine $v$. California to read the handwriting on our own wall. In the interim between Irvine $v$. California and People v. Cahan it became all too clear in our state that there was no recourse but to the exclusionary rule. In the interim between Irvine $v$. California and Mapp v. Ohio a like reflection of nation-wide import must also have been developing in the Supreme Court of the United States. Its decision in Irvine had intimated a hope that in time the many states still uncommitted to the exclusionary rule would reconsider their evidentiary rules in the light of the Wolf doctrine that the fourth amendment is enforceable against the states through the fourteenth. The indifferent response must have been disheartening to a Court that had expressed its reluctance to invoke federal power to upset state convictions based on unconstitutionally obtained evidence.

The many states that failed even to re-examine their evidentiary rules merely postponed the day of reckoning. They had clear warning in Irvine that if they defaulted and there were no demonstrably effective deterrents to unreasonable 
searches and seizures in lieu of the exclusionary rule, the Supreme Court might yet decide that they had not complied with "minimal standards" of due process. When in 1961 it so decided in Mapp v. Ohio and made the exclusionary rule mandatory in all states, it could hardly have taken anyone by surprise. For all their distracting, discordantly nay-saying chimes, the hours had been successively striking that the zero hour was coming. ${ }^{18}$

Of late, however, we can no longer say that the hours have been successively striking to give states warning that the zero hour is coming. They seem to be striking all at once, as though there were gremlins intent on their own solos in the clockworks. Since all the courts in the land must keep time with the highest court, the time has come to inquire whether the controlling clockworks are running faster and more furiously than need be to do poetic justice to slow-moving states. ${ }^{19}$ I proceed to the inquiry with all deliberate speed from the vantage point, or rather the disadvantage point, of a state judge.

There is no need of fresh reports to confirm that judicially speaking, all is not quiet along the western front or any other front. Not so long ago there was more cause than now to be optimistic about the harmonious integration of federal rules into state criminal procedure. There was at least grumbling acceptance in the states of constitutional rules that raised standards of procedure above the misery level of coerced confessions and knowing use of perjured testimony. Reasonable men knew, or should have known, that in a country of steadily rising expectations, we could not forever tolerate such gross abuses of justice. There was even grumbling acceptance of Mapp $v$. Ohio in $1961,{ }^{20}$ for when roughly half the states already had an equivalent rule, ${ }^{21}$ the inhabitants of sister states could hardly complain that they had been taken by surprise.

Nevertheless, Mapp v. Ohio, for all the predictability of its basic rule, was clouded with enough obscurities to confound the most cooperative state courts. It left in limbo the plain question, lately settled, of retroactivity. ${ }^{22}$ It left in limbo the problem of harmless error. ${ }^{23} \mathrm{It}$

18 Traynor, Mapp v. Ohio at Large in the Fifty States, 1962 Duke L.J., 319, 323-24 (footnotes in original omitted).

19 See Friendly, The Bill of Rights as a Code of Criminal Procedure, 53 CALIF. L. Rev. 929, 930 (1965).

20 See, e.g., Inbau, Law Enforcement, The Courts, and Individual Civil Liberties, in CRIMINal Justice IN OUR Time 97, 120 (Howard ed. 1965).

21 See Elkins v. United States, 364 U.S. 206, 224-25 (1960).

22 See Linkletter v. Walker, 381 U.S. 618 (1965).

23 See Fahy v. Connecticut, 375 U.S. 85 (1963); People v. Parham, 60 Cal. 2d 378, 385- 
left in limbo the still troublesome problem of the power of federal courts to upset final judgments of state courts on writs of habeas corpus. ${ }^{24}$ It left in limbo the confusing question of when federal rules should displace state rules in determining whether a search or seizure was unreasonable. ${ }^{25}$ It made no mention of the hopeless confusion in the federal rules themselves. ${ }^{26}$

There were other rules that joined with Mapp $v$. Ohio to roam at large in the fifty states. ${ }^{27}$ They engendered so much irrational fear, particularly among those who automatically mistrust anything that dis-

86, 384 P.2d 1001, 1005, 33 Cal. Rptr. 497, 501 (1963), cert. denied, 377 U.S. 945 (1964);

64 Colum. L. Rev. 367 (1964).

24 See Fay v. Noia, 372 U.S. 391 (1963); Townsend v. Sain, 372 U.S. 293 (1963).

25 Two years later, in Ker v. California, 374 U.S. 23 (1963), the Court held that although the standard of reasonableness is the same under the fourth and fourteenth amendments, "The States are not thereby precluded from developing workable rules governing arrests, searches and seizures to meet "the practical demands of effective criminal investigation and law enforcement' in the States, provided that those rules do not violate the constitutional proscription of unreasonable searches and seizures. . . ." Id. at 33-34. It also pointed out that "the demands of our federal system compel us to distinguish between evidence held inadmissible because of our supervisory powers over federal courts and that held inadmissible because prohibited by the United States Constitution," and it recognized that in some cases the question of reasonableness itself may turn on compliance with statutory rules that might constitutionally vary. Ibid. Thus, in applying the rule that a search incident to a lawful arrest may be made without a warrant, it stated: "This Court, in cases under the Fourth Amendment, has long recognized that the lawfulness of arrests for federal offenses is to be determined by reference to state law insofar as it is not violative of the Federal Constitution. Miller $v$. United States, supra; United States v. Di Re, 332 U.S. 581 (1948); Johnson v. United States, 333 U.S. 10, 15, n.5 (1948). A fortiori, the lawfulness of . . . arrests by state officers for state offenses is to be determined by ... [state] law" 374 U.S. at 37 .

In a recent opinion I noted: "Ker $v$. California has now recognized that the purpose of the distinction between constitutional and supervisory rules is to separate fundamental civil liberties, which the states must respect, from federal procedural rules, which the states may ignore. Opinions written before this distinction assumed its present crucial importance may have to be reinterpreted in the light of the demands of our federal system." " People v. Thayer, 63 Cal. 2d 664, 668, 408 P.2d 108, 110, 47 Cal. Rptr. 780, 782 (1965); see also Friendly, supra note 19, at 938-40. It follows that "before a state rule governing police conduct may be struck down, it must appear that neither Congress nor a state legislature could authorize it. If a state adopts rules of police conduct consistent with the requirements of the Fourth Amendment and if its officers follow those rules, they do not act unreasonably within the meaning of the amendment although different rules may govern federal officers." People v. Mickelson, 59 Cal. 2d 448, 452, 380 P.2d 658, 660, 30 Cal. Rptr. 18, 20 (1963).

26 See Traynor, supra note 18 , at $329-33$.

27 Jackson v. Denno, 378 U.S. 368 (1964) (voluntariness of confession must not be tried by jury that tries guilt); Murphy v. Waterfront Commission, 378 U.S. 52 (1964) (compulsion of testimony by one jurisdiction requires immunity from prosecution based on compelled testimony in all jurisdictions); Fay v. Noia, 372 U.S. 391 (1963) (extension of federal habeas corpus for state prisoners); Townsend v. Sain, 372 U.S. 293 (1963) (extension of right to evidentiary hearing for state prisoners in federal habeas corpus proceeding). 
turbs their routine ways, that many thoughtful observers hesitated to voice rational misgivings lest their own voices would become commingled with the emotional hue and cry. ${ }^{28}$ The time finally came, however, when even such taciturn observers could no longer remain tacit in view of a mounting crisis. ${ }^{29}$ We confront that crisis now in the constitutional rules that reach out to govern police interrogation.

These rules compel us to take a new look at the rules that have evolved on confessions, for they are the other side of the coin. Under the fifth amendment ${ }^{30}$ and similar provisions in virtually all state constitutions, ${ }^{31}$ one accused of crime can remain silent and thus compel the state to assume the entire burden of proving his guilt. In theory, this privilege against self-incrimination is a mighty defense against conviction of guilt.

In practice, however, most defendants have not availed themselves of the privilege. At the trial they often plead guilty because they are aware there is already a strong case against them. Sometimes they plead guilty because they are willing to accept just punishment or because they deem it expedient to give up their right to a trial in exchange for a reduced charge or lesser sentence. ${ }^{32}$ There is nothing wrong with such pleas, in effect judicial confessions, if they have not been induced by antecedent illegal conduct of police or prosecutors.

Likewise, there is nothing wrong with extrajudicial confessions that have been legally obtained. Confessions are such cogent evidence of guilt that they often serve to induce pleas of guilty or to expedite trials. ${ }^{33}$ Hence police and prosecutors routinely seek to elicit them by interrogation and often succeed. ${ }^{34}$ There is always a high risk of direct or in-

28 See Traynor, Lawbreakers, Courts, and Law-Abiders, 31 Mo. L. Rev. 181 (1966). 29 See, e.g., Friendly, supra note 19.

30 "No person ... shall be compelled in any criminal case to be a witness against himself. . . ." U.S. Consr., amend. v.

31 The exceptions are Iowa and New Jersey. In Iowa the privilege has been read into the state constitution by the courts. Amana Society v. Seltzer, 250 Iowa 380, 94 N.W.2d 337 (1959); State v. Height, 117 Iowa 650, 91 N.W. 935 (1902). In New Jersey the privilege has been adopted by statute. N.J. Stat. ANN. § 2A:84A-17, 19 (Supp. Oct. 1965). See generally 8 WIGMORE, EvidENCE, § 2252 (McNaughton rev. 1961).

32 See Traynor, supra note 28 , at 188.

33 On the role of confessions in law enforcement compare Sobel, The Exclusionary Rules in the Law of Confessions, A Legal Perspective-A Practical Perspective, Part VI, N.Y.L.J., Nov. 22, 1965, pp. 1, 4-5, with Statements of former New York City Police Chief Michael Murphy, N.Y. Times, Nov. 20, 1965, p. 1, col. 5, and Statements of New York County District Attorney Frank Hogan, N.Y. Times, Dec. 2, 1965, p. 1, col. 2.

34 Tactics of interrogation to elicit confessions are set forth in many police manuals. See arthur and Caputo, Interrogation for Investigators (1959); Inbau \& Reid, CrimINAL INTERRogation AND CONFESSIONS (1962); INBAU AND REID, LIE DETECTION AND CRIMinal Interrogation (3d ed. 1953); Kidd, Police Interrogation (1940); Mulbar, Interrogatron (1951); O'Hara, Fundamentals of Criminal Investigation (1956). For critical 
direct coercion in such a process, however, because of its secrecy. ${ }^{35}$ Such excessive violations as have come to the attention of the United States Supreme Court have prompted it to formulate exclusionary rules directed against overreaching inquisition.

Until the Escobedo case the touchstone of admissibility under the due process clause of the fourteenth amendment was the voluntariness of the confession. The case for exclusion is clearest when police or prosecutors have resorted to procedures that might induce a false and hence an untrustworthy confession. Violence or threats of violence against the accused or those close to him may induce a false confession. ${ }^{36}$ Promises of leniency may also have this effect. ${ }^{37}$

Untrustworthiness, however, has rarely been the sole reason for excluding an involuntary confession. Even the earliest cases adumbrate an enlarged test of due process transcending the simple one of untrustworthiness. ${ }^{38}$ Though the Court invoked untrustworthiness as a basis for exclusion, it took care to note the "fundamental unfairness" of oppressive tactics and their demoralizing effect on human dignity. ${ }^{39}$

comments thereon see Brief for the American Civil Liberties Union as Amicus Curiae, pp. 5-8, Escobedo v. Illinois, 378 U.S. 478 (1964); Kamisar, What is an "Involuntary" Confession? Some Comments on Inbau and Reid's Criminal Interrogation and Confessions, 17 Rutgers L. Rev. 728 (1963); Weisberg, Police Interrogation of Arrested Persons: A Skeptical View, 52 J. CRIM. L., C. \& P.S. 21, 22-26 (1961), reprinted in POLICE POWER AND INDIvidViAL FREedom 153, 155-58 (Sowle ed. 1962).

35 "In the police station a prisoner is surrounded by known hostile forces. He is disoriented from the world he knows and in which he finds support. He is subject to coercing impingements, undermining even if not obvious pressures of every variety. In such an atmosphere, questioning that is long continued-even if it is only repeated at intervals, never protracted to the point of physical exhaustion-inevitably suggests that the questioner has a right to, and expects, an answer. That is so, certainly, when the prisoner has never been told that he need not answer and when, because his commitment to custody seems to be at the will of his questioners, he has every reason to believe that he will be held and interrogated until he speaks." Culombe v. Connecticut, 367 U.S. 568, 575-576 (1961) (opinion of Frankfurter, J.).

36 See Malinski v. New York, 324 U.S. 401,407 (1945); Ashcraft v. Tennessee, 322 U.S. 143, 160 (1944) (Jackson, J., dissenting).

37 Experts on interrogation agree that confessions elicted by promises of leniency should be inadmissible. See Inbau \& REID, Criminal INTERrogation and CoNfessions 112 (1962); Leyra v. Denno, 347 U.S. 556 (1954). See also Escobedo v. Illinois, 378 U.S. 478 , 483-484 (1964); Lynumn v. Illinois, 372 U.S. 528 (1963).

38 The earliest Supreme Court case to discuss the underlying rationale for exclusion was Lisenba v. California, 314 U.S. 219 (1941). In his opinion for the court, Mr. Justice Roberts observed that "the aim of the rule that a confession is inadmissible unless it was voluntarily made is to exclude false evidence." He went on to state that "the aim of the requirement of due process is not to exclude presumptively false evidence, but to prevent fundamental unfairness in the use of evidence, whether true or false." Id. at 236. He apparently envisaged two confession rules: a rule of evidence excluding untrustworthy confessions and a constitutional rule banning unfair pressures even if the resulting confession is reliable.

39 See Ashcraft v. Tennessee, 322 U.S. 143, $159-60$ (1944) (Jackson, J., dissenting); Lisenba v. California, 314 U.S. 219, 236 (1941). 
The Court also took note of the marked contrast between the orderly and open procedures of the courtroom and the often unruly and secret procedures of the police. ${ }^{40}$ In recent cases the Court has clearly graduated to this broadened concept of due process. ${ }^{41}$

Sometimes the police have pursued their interrogation not only without legal authority, but in deliberate violation of specific provisions of federal or state law. Thus there have been violations of rule 5(a) of the Federal Rules of Criminal Procedure and comparable state statutes and rules of court. ${ }^{42}$ Under rule $5(a)$ an arrested person must be brought before a magistrate "without unnecessary delay." Apparently the police have nevertheless acted on the belief that they could obtain more confessions by violating the rule than by obeying it, a plain inference from their vehement objections to the $M c N a b b$ Mallory rule. ${ }^{43}$ They continue their violations in the states with impunity, for only Michigan and Connecticut have adopted an equivalent of the $M c N a b b-M a l l o r y$ rule to deter violations of their own prompt-arraignment statutes or rules of court. ${ }^{44}$

40 In the early case of Ashcraft v. Tennessee, 322 U.S. 143 (1944), Mr. Justice Black's opinion for the Court stated, "It is inconceivable that any court of justice in the land, conducted as our courts are, open to the public, would permit prosecutors serving in relays to keep a defendant witness under continuous cross-examination for thirty-six hours without rest or sleep in an effort to extract a 'voluntary' confession. Nor can we, consistently with Constitutional due process of law, hold voluntary a confession where prosecutors do the same thing away from the restraining influences of a public trial in an open court room." Id. at 154. In amplification he quoted the Supreme Court of Arizona: "The aid of counsel in preparation would be farcical if the case could be foreclosed by a preliminary inquisition which would squeeze out conviction or prejudice by means unconstitutional if used at the trial." $I d$. at $155 \mathrm{n}$.10. It does not follow that behavior outside the courtroom must conform precisely to the meticulous procedures of the courtroom. Otherwise all convictions based on coerced confessions would be reversed whenever the behavior of the police did not correspond to the required behavior of the prosecutor in the courtroom. See Kamisar, Equal Justice in the Gatehouses and Mansions of American Criminal Procedure: From Powell to Gideon, From Escobedo to - in CRTMINAL Justice IN OUR TMME 1, 12-13 (1965). Nevertheless, police procedures must not do violence to rights observed in the courtroom. See Comment, The Coerced Confession Cases in Search of a Rationale, 31 U. CHr. L. REv. 313, 320-25 (1964).

41 Rogers v. Richmond, 365 U.S. 534 (1961); Blackburn v. Alabama, 361 U.S. 199 (1960); Spano v. New York, 360 U.S. 315 (1959).

42 Consistent violations are set forth in AII Moded Code of Pre-Arraignment ProCEDURE, 135-36 (Tent. Draft No. 1, 1966).

43 See Hearings Before Subcommittee No. 2 of the House Committee on the Judiciary, 78th Cong., 1st Sess. 1, 43 (1944); Hearings Before the Subcommittee on Improvements in the Federal Criminal Code of the Senate Committee of the Judiciary, 85th Cong., 2d Sess. 124 (1958). See also Inbau, The Confession Dilemma in the United States Supreme Court, 43 ILL. L. REv. 442, 459-60 (1948); Scott, The Mallory Decision and the Vanishing Rights of Crime Victims, Police, July-August, 1960, p. 28; Waite, Police Regulation by Rules of Evïdence-Results of the McNabb Case, 42 Micr. L. REv. 909 (1944).

44 People v. Hamilton, 359 Mich. 410, 102 N.W.2d 738 (1960); ConN. GEN. STAT. ANN. § 54-1(c) (Supp. 1964). 
The $M c N a b b-M a l l o r y$ rule represents an attempt to diminish the problem of judging whether a confession is voluntary as well as to deter official lawlessness. The Court has yet to extend the rule to the states, ${ }^{45}$ but few would dispute that it has more than filled the breach, not merely by ruling that prolonged detention may be inherently coercive, ${ }^{46}$ but also by establishing a right to counsel at the prearraignment stage. ${ }^{47}$

Thus one finds in the coerced confession cases intermingling strains: a rule of evidence on untrustworthiness expanded into a rule with constitutional overtones; a constitutional rule, phrased in terms of due process, at first bearing close kinship to the rule on untrustworthiness but gradually quitting itself of so narrow a compass; and a federal rule designed to foster observance of prompt arraignment. There is still another strain running through the cases, the fifth amendment privilege against self-incrimination. It has made history, and it is still making news.

The privilege against self-incrimination was first applied to a confession out of court in a federal prosecution in Bram v. United States ${ }^{48}$ in 1897. For many years thereafter the United States Supreme Court consistently refrained from extending the privilege to the states under the due process clause of the fourteenth amendment, ${ }^{49}$ but there were portents in the cases that there would be such an evolution. ${ }^{50}$ It materialized in Malloy v. Hogan ${ }^{51}$ in 1964. The evolution was fostered, as Mr. Justice Brennan noted in his opinion for the Court, by the gradual shift in the basis for the exclusion of coerced confessions from the purported untrustworthiness of such testimony to grounds of due process that in time became virtually indistinguishable from the privilege against self-incrimination. ${ }^{52}$ Once the privilege was clearly recognized as operative to inhibit state police interrogations, it was a fortiori applicable to inhibit interrogations in state judicial proceedings.

By the time Malloy $v$. Hogan extended the fifth amendment to the states the sixth amendment had also made news. In Gideon v. Wain-

\footnotetext{
45 See note 8 supra.

46 Ashcraft v. Tennessee, 322 U.S. 143 (1944).

47 See note 4 supra.

48168 U.S. 532 (1897). Compare Powers v. United States, 223 U.S. 303, 313-14 (1912).

48 Adamson v. California, 382 U.S. 46 (1947); Twining v. New Jersey, 211 U.S. 78 (1908).

50 See Haynes v. Washington, 373 U.S. 503, 513 (1963); Gallegos v. Colorado, 370 U.S. 49, 51 (1962); Mapp v. Ohio, 367 U.S. 643, 656-57 (1961); Culombe v. Connecticut, 367 U.S. 568, 583 n.25 (1961) (Frankfurter, J.); id. at 639 (Douglas J., concurring); Leyra v. Denno, 347 U.S. 556, 558 n.3 (1954); Ashcraft v. Tennessee, 322 U.S. 143, 154 n.9 (1944).

51378 U.S. 1 (1964).

$52 I d$. at 6-9.
} 
wright ${ }^{53}$ the United States Supreme Court extended the right to counsel to state defendants. In Massiah 7 . United States ${ }^{54}$ it held that the right to counsel does not await formal judicial proceedings, but arises when the defendant is indicted. It was against this background that the Court in Escobedo v. Illinois ${ }^{55}$ announced a right to counsel before indictment, and held inadmissible a suspect's damaging statement elicited by police interrogation in the absence of counsel.

The case might well have been decided under existing rules. In extending the right to counsel to the prearraignment stage, the Court promulgated a rule not only of dim contours but also of hazy constitutional derivation from the sixth amendment. ${ }^{56}$ Though there had been a drift in this direction, ${ }^{57}$ there was scant warning that the Court would so swiftly take command of an area that the states might well have

53372 U.S. 335 (1963).

54377 U.S. 201 (1964).

55378 U.S. 478 (1964).

56 "In all criminal prosecutions, the accused shall enjoy the right . . to have the assistance of counsel for his defense." U.S. ConsT., amend. VI.

57 In 1958 the Supreme Court of the United States rejected the contention that there was an absolute right to counsel during police interrogation. Crooker v. California, 357 U.S. 433 (1958); Cicenia v. LaGay, 357 U.S. 504 (1958). There were sharp dissents by Chief Justice Warren and Justices Douglas, Black, and Brennan, who insisted that such denial of counsel was a deprivation of due process. Crooker v. California, 357 U.S. at 443-44. When the Court considered the same question in the context of a suspect who had been indicted, Mr. Justice Stewart added his vote to those of the Crooker and Cicenia dissenters and urged that there was an absolute right to counsel after indictment. Spano v. New York, 360 U.S. 315, 326 (1959). Chief Justice Warren, however, voted with those Justices who reversed Spano's conviction, on the ground that the totality of the circumstances revealed that his confession was coerced. There were thus five Justices who, in one case or another, had supported a rule that would exclude confessions obtained after a denial of a request for counsel once an indictment had been returned.

The states, meanwhile, were attempting to develop workable solutions to the right to counsel problem. The New York Court of Appeals, in accord with Mr. Justice Stewart's concurrence in Spano, held that a defendant who is interrogated by the police after indictment has an absolute right to counsel even in the absence of a request for counsel. People v. DiBiasi, 7 N.Y.2d 544, 166 N.E.2d 825, 200 N.Y.S.2d 21 (1960). The New York court held that an interrogation that did not conform to this rule deprived the accused not only of his right to the assistance of counsel, but also of his right to be free from testimonial compulsion. People v. Waterman, 9 N.Y.2d 561, 564, 175 N.E.2d 445, 447, 216 N.Y.S.2d 70, 74 (1961). The rule was soon extended to statements made after arraignment but before indictment. People v. Meyer, 11 N.Y.2d 162, 182 N.E.2d 103, 227 N.Y.S.2d 427 (1962). When the inevitable confrontation of the problems during prearraignment interrogation arrived, the New York Court of Appeals held that the defendant's rights were violated only when he had specifically requested counsel or when retained counsel was denied the opportunity to confer with the defendant. People v. Donovan, 13 N.Y.2d 148, 193 N.E.2d 628, 243 N.Y.S.2d 841 (1963). See also People v. Gunner, 15 N.Y.2d 226, 205 N.E.2d 852, 257 N.Y.S.2d 924 (1965).

The Oregon Supreme Court rejected the DiBiasi rule, see State v. Kristich, 226 Ore. 240, 359 P.2d 1106 (1961), as did the concurring opinion in People v. Garner, 57 Cal. 2d 135, 165, 367 P.2d 680, 698, 18 Cal. Rptr. 40, 58 (1961). 
undertaken to develop comprehensively. Reasonable men could hardly foresee that the provinces would be deemed delinquent in their due process for failing to take one great leap from the right to counsel at trial to a right to counsel before arraignment.

There is no predicting whether such rules governing detention will prove to be angels or fallen angels of due process, but at this juncture they bear a pointed resemblance to devil's advocates. We can at least give them their due by conceding them a shock value of potential benefit; they could serve to quicken the states to modernize their criminal procedures. One can then expect much soul searching as to just how expansive a due we want in the moving picture of due process. Most lawyers are familiar with the sound track of the current serial, and I quote it here only that we may register how sweetly reasonable are its sounds before noting how diabolically elusive are its grounds. The rule of Escobedo v. Illinois reads:

We hold, therefore, that where, as here, the investigation is no longer a general inquiry into an unsolved crime but has begun to focus on a particular suspect, the suspect has been taken into police custody, the police carry out a process of interrogations that lends itself to eliciting incriminating statements, the suspect has requested and been denied an opportunity to consult with his lawyer, and the police have not effectively warned him of his absolute constitutional right to remain silent, the accused has been denied "the Assistance of Counsel" in violation of the Sixth Amendment to the Constitution .... and that no statement elicited by the police during the interrogation may be used against him at a criminal trial. 58

I have no quarrel with the result in the Escobedo case, given its facts. The Court's reliance on the sixth amendment under cover of the fourteenth, however, apparently makes available to any suspect a full-blown right to counsel at the incipient accusatory stage when police interrogation shifts from general inquiry to a probe focusing upon him. The Court was unconcerned with the problem of selecting which moment in time to impale as the crucial moment of focus. Even more disconcerting to the front lines, it gave no heed to spelling out any exceptions to a full-blown right to counsel. Does the right arise in the police station, in the police wagon, or in the street? Does it apply to all possibilities of incrimination such as voice identifications, fingerprints, handwriting exemplars, or blood tests? ${ }^{59}$ Though a judge may invoke

58378 U.S. at $490-91$.

59 See People v. Graves, 64 A.C. 216, 411 P.2d 114, 49 Cal. Rptr. 386 (1966). 
the privilege of not answering such questions outside of working hours, he is bound on the job to do so.

At least one thing seems clear: the Court could hardly have intended to limit the right to those who had requested counsel, for it would then turn on the incantation, knowing or naive, of the magic words calling for counsel. Such a reading would not be consonant with the Court's own recent decisions on the sixth amendment right. ${ }^{60}$ In faithfulness to these decisions as well as to the Escobedo decision, the California Supreme Court accordingly felt bound to hold in People v. Dorado61 that the right to counsel established in the Escobedo case did not turn on a request for counsel.

A faithful state court feels bound thus to take the supreme law of the land at face value, however veiled the rationale and hence however vulnerable to liquidation or revision. It cannot fly in the face of that veiled face value, even though its superior is free to discount it at any time. Though it may struggle to give intelligible local application to such a text as the Escobedo opinion, the public grows understandably restive at taking program of sweeping reach without adequate warning or explanation from the original promulgators. They do not ask for a promptbook, but only for clear and orderly transitions in the progressive spelling of due.

Given the now widely recognized need for more light on the whole area of police procedures, the fixation of the Escobedo rule on the sixth amendment right to counsel may have been intended as a miracle of floodlighting. Instead, it achieved a success in flooding the area rather than lighting it, beyond the visions of even such a demon as Till Eulenspiegel. Perhaps there was a more limited intention, to set in rapid motion the privilege against self-incrimination at the detention stage in sequence of the Court's recognition in Malloy v. Hogan that the privilege had long been operative at that stage, even if not under its own name. ${ }^{62}$ The Escobedo opinion itself suggests such a concern with the fifth amendment. ${ }^{63}$ When it reached instead for the

60 A request for counsel is a "formality upon which [defendant's] right may not be made to depend." Carnley v. Cochran, 369 U.S. 506, 514 (1962), and cases there cited. See Note, 19 Rutgers L. REv. III (1964).

6162 Cal. 2d 338, 398 P.2d 361, 42 Cal. Rptr. 169 (1964), cert. denied, 381 U.S. 937 (1965).

62 See note 50 supra.

63 Escobedo v. Illinois, 378 U.S. $478,488-90$ (1964). If the Court's concern was to protect Escobedo's privilege against self-incrimination, the denial of his request to consult with his counsel might have been viewed as vitiating the privilege. Escobedo had made clear that he wished the advice of counsel before answering questions. His privilege not to answer was violated when the police disregarded his wishes and overwhelmed him by secret interrogation that included false accusations. 
sixth amendment right to counsel, it unhappily put everything at sixes and sevens within the fourteenth.

Even assuming the possibility of waiver of the right to counsel, the police may be reluctant to determine so disputable a legal question. ${ }^{64}$ Accordingly, they may hesitate to elicit evidence from a suspect that he is willing or even eager to divulge. The adage is particularly pertinent here that he who hesitates is lost. Thus if the police fail to make prompt inquiry into a suspected criminal conspiracy, they risk losing what might be their only opportunity to obtain evidence of such a conspiracy. Nevertheless they may still be unwilling to question any suspected conspirator unattended by counsel, for if they then ran counter to the Escobedo rule they would immunize the suspect from prosecution on the basis of the evidence he divulged that afforded grounds for prosecution.

So rudely turned are the tables that the police must now confront any suspect with diffidence, instead of the other way round. There can be real damage to an innocent suspect in consequence. It sometimes happens that an innocent person is arrested lawfully, though in error; he can be promptly released only if the police have some latitude to question him and in that way learn that he should be released. To constrain reasonable questioning may work to constrain the innocent. $^{65}$ In lieu of interrogation that could have cleared an innocent suspect, the police are likely to resort to formal charges to hold him in custody until such time as he is attended by counsel, either retained by him or provided for him if he is indigent. ${ }^{68}$

If the police fail deliberately or inadvertently to advise him of his right to counsel, a knowing suspect could misuse due process by freely making incriminating admissions and then invoking the sixth amendment at the trial to escape their consequences. Caught between such a devil and the deep waves of the sixth amendment, the police might

64 There is a presumption against waiver of fundamental constitutional rights, including the right to counsel. Johnson v. Zerbst, 304 U.S. 458, 464 (1938). An accused who waives his right to counsel in the police station may later claim that the waiver was not voluntary. The court will then have to determine, ordinarily from contradictory testimony, whether the accused "intelligently and knowingly waived his privilege against self-incrimination and his right to counsel. . . " Escobedo v. Illinois, 378 U.S. 478, 490 n.14 (1964). See Developments in the Law-Confessions, 79 HARv. L. REv. 935, 1006-07 (1966).

65 See ALI Model Code of Pre-Arraignment Procedure 144-46 (Tent. Draft. No. 1, 1966).

66 There are obvious difficulties in providing for the presence of counsel in the stationhouse whenever the police may have occasion to question a suspect. See ALI ModeI Code of Pre-Arraignment Procedure \& 5.07, comment at 191 (Tent. Draft No. 1, 1966); Enker \& Elsen, Counsel for the Suspect: Massiah v. United States and Escobedo v. Illinois, 49 MinN. L. REv. 47, 78 (1964); Note, 73 YALE L.J. 1000, 1046 (1964). 
eventually retreat into an indifference to their responsibilities no less foreboding for the integrity of criminal procedure than excesses of zeal.

Their major frustration arises from the satanic two-pronged question of the Escobedo rule. When does an investigation cease to be "a general inquiry into an unsolved crime"? When does it begin "to focus on a particular suspect"? There is more of Lucifer than of luciferousness in a rule that compels a police officer, even under emergency conditions, to make so finespun a determination. In the very case where it formulated so nebulous a test, the Supreme Court quit itself of another nebulous test, namely, the two-pronged voluntary-involuntary test of admissibility of a confession. It was quite a jump from the frazzled touchstone of involuntariness to the brimstone fire of focus.

Consider the questions within the question of Focus, Focus, on the spot: What is due process? What is not? Imagine yourself a police offcer confronting one or more suspects. You may also be speculating on a number of hypotheses to solve the crime. Will you be held to a strictly objective standard of reasonableness or to a more lenient standard comparable to the best business judgment test?67 Given the reluctance of courts to question the judgment of corporate directors, on the grounds of the complexities of business, will they also be reluctant to question the judgment of police officers because of the complexities and perplexities of crime detection?

The complexities and perplexities are endless. For example, suppose you catch someone in the act of robbery, who becomes the accused with respect to that crime and is also a suspect with respect to similar unsolved crimes. Under the Escobedo rule your interrogation cannot be of a piece, because in the first situation there is a right to counsel, though in the second there is not. Can you organize your interrogation in compartments with a view to uncovering information on the unsolved robberies?

Suppose, instead, you capture someone in the act of committing a crime, and wish now to question him for the purpose of apprehending his confederates. Is your focus already so intently upon him that even such questioning would be encompassed within the focus?

Suppose you come upon a person in illegal possession of narcotics who may be of greater interest to the police in the investigation of the narcotics traffic than as an accused. If you proceed to interrogate him in that broader context, have you also focused upon him, thereby fixing the moment of his right to counsel?

67 See 3 Fletcher, Cyclopedia of the Law of Private Corporations $\S 1039$ (Perm. ed. 1965). 
So vague a test for the right to counsel as the moment of focus is bound to engender continual disputation on a point in time, when the concern should be with the overall fairness of police interrogation. Neither should the right to counsel turn on a moment arbitrarily fixed as the beginning of judicial proceedings, such as the moment of arrest or custody. ${ }^{68}$ In 1961, before Massiah $v$. United States ${ }^{69}$ and McLeod v. Ohio ${ }^{70}$ held that the right to counsel arises no later than indictment, I rejected such a marker as formulistic. Moreover, I noted that "if the suspect is in custody before indictment, the police could easily frustrate the rule by delaying the indictment. . .."71 Even assuming that such a formula might prevail to mark the time when a right to counsel materialized, I took the view that the right to counsel would not invariably compel the presence of counsel at a police interrogation of the accused.

The United States Supreme Court decided otherwise. The Massiah and $M c L e o d$ cases hold that once the right to counsel materializes, the accused cannot be questioned in the absence of counsel unless he has effectively waived his right. Presumably the right could materialize also when a warrant for the arrest of the accused has issued or when he has been brought before a judicial officer following his arrest without a warrant. The logical corollary, to forestall evasion of the rule, seems just around the corner. The right to counsel should now logically materialize whenever the accused was not, but should have been, brought before a judicial officer.

It is a fair speculation that some of the confusion engendered by the Escobedo opinion could have been obviated had the Court based its decision on the fifth amendment privilege against self-incrimination instead of on the sixth amendment right to counsel. There was already a coherent progression of cases based on the fifth amendment whose evolutionary rationale could appropriately have been extended to the Escobedo case. ${ }^{72}$ Moreover, every state except Iowa and New Jersey already had an equivalent of the fifth amendment in its own constitution, and even New Jersey had a comparable provision in its statutes. ${ }^{73}$

68 People v. Garner, 57 Cal. 2d 135, 164, 367 P.2d 680, 697-98, 18 Cal. Rptr. 40, 57-58 (1961) (concurring opinion).

69377 U.S. 201 (1964).

70.381 U.S. 356 (1965).

71 People v. Garner, 57 Cal. 2d 135, 164, 367 P.2d 680, 698, 18 Cal. Rptr. 40, 58 (1961) (concurring opinion).

72 See Malloy v. Hogan, 378 U.S. 1, 6-9 (1964); Sutherland, Crime and Confession, 79 HARV. L. REv. 21, 30-31, 35-37 (1965).

73 See note 31 supra. 
Once Malloy $v$. Hogan established that the privilege against selfincrimination operated with the force of the United States Constitution in both state judicial proceedings and in state police interrogations, its logic could have been extended to the Escobedo case to preclude secret inquisition resistant to proof of coercion. Since the police can easily act without authority, a suspect could with even greater logic invoke the privilege within their arcane confines than in the openly regulated courtroom. It is casuistic to pretend that because the police have no legal authority to compel statements of any kind, ${ }^{74}$ there is nothing to counteract and hence no need of a privilege against self-incrimination during police interrogation. ${ }^{75}$

The fifth amendment has long been the life of the party in judicial or legislative proceedings, but it has had no life it could call its own in the prearraignment stage. Prosecutors seemed disposed to live happily ever after with this double standard. It eased their heavy burden of proof byond a reasonable doubt at the trial if they could preassemble the evidence before trial, at no great risk of detection, with the suspect's unwilling or unwitting self-incrimination. ${ }^{76}$ Even as to gross violations of the privilege it was the exception rather than the rule when the double standard came to light in an occasional test case. On each such occasion the wails of law enforcement officers and the reinforcing public chorus of woe spoke volumes as to the prevalence of the double standard. ${ }^{77}$

Did we or did we not believe in the privilege against self-incrimination? There was never a real confrontation of the question so long as there was a double standard of the privilege. Although we took it for granted that suspects did incriminate themselves at the prearraignment stage in fear or ignorance, so that in the courtroom they were already

74 See McNaughton, The Privilege Against Self-Incrimination: Its Constitutional Affectation, Raison d'Etre and Miscellaneous Implications, 51 J. CRIM. L., C. \& P.S. 138, $151-52$ (1960); Comment, 31 U. CHI. L. Rev. 556, 559-65 (1964); Note, 112 U. PA. L. REv. $210,248-49$ (1963).

75 See Kamisar, supra note 40, at 12-19.

76 "Those who generations from now set out to write the history of our legal institutions will puzzle over a framework of criminal justice, which, during a public trial before an impartial judge with defense counsel present to give aid, will not suffer the defendant to be asked a single question without his consent. And yet that same legal system will condone the relentless questioning in secret at all hours of the day and night of that same defendant with only those whose duty it is to ensnare him to determine where the line between fair and foul is to be drawn. This is a tragic indictment of contemporary society. The preaching of one thing and the practicing of another is often one of the first warnings of socal decay." Hogan \& Snee, The McNabb-Mallory Rule: Its Rise, Rationale and Rescue, 47 Geo. L.J. 1, 25-26 (1958). See Packer, Two Madels of the Criminal Process, 113 U. PA. L. Rev. I (1964).

77 See Traynor, supra note 28 at $197-98$. 
damned by their own admissions, we guarded their privilege in court with great ceremony. There they could keep their golden silence. The gold standard began to appear questionable only when it threatened to become a single standard, applicable at the prearraignment stage as well as in court. One seldom heard, however, that we should give thought to going off the gold standard by revising the fifth amendment to permit some degree of self-incrimination in open procedures, whether at the trial or pretrial stage. ${ }^{78}$ That might have seemed too much like removing the picture of a venerable ancestor out of its ornate frame in the parlor and reclaiming the unfinished sketch in the basement, with a view to framing both within harmonious modern borders the better to display their resemblance. We have resisted making either transformation, because we have grown uncritically accustomed to the ornate frame and until recently we have been indifferent to the unfinished sketch.

Should there now be a development of the inchoate privilege against self-incrimination at the prearraignment stage, much would be gained and nothing lost if it were developed, not as an identical twin of the privilege in judicial or legislative proceedings, but as a workable counterpart.

A workable counterpart must strike a common-sense balance between a suspect's privilege against self-incrimination and the community's right to legitimate police investigation, not only to discover who has perpetrated a crime, but to rule out who has not. There must be a middle ground in due process that affords fair protection to an individual against the state without thwarting efforts of the state to pursue the investigation of crime. On such a middle ground we could establish a correlation between trial and prearraignment procedures that might well operate to bring a pervasive openness to prearraignment procedures in which rules could operate with reasonable flexibility instead of as martinets. Such an environment would of itself militate against more than such gross abuses as coerced confessions. It would militate against techniques that insidiously impel a suspect to make admissions with blunted awareness of their damaging effect. ${ }^{79}$ It would

78 Such a procedure was suggested by Kauper, Judicial Examination of the AccusedA Remedy for the Third Degree, 30 Mrch. L. Rev. 1224 (1932), and Pound, Legal Interrogation of Persons Accused or Suspected of Crime, 24 J. CRIM. L., C. \&c P.S. 1014 (1934). A similar procedure was proposed for South Africa by a judge of the Supreme Court of South Africa. See Hiemstra, Abolition of the Right Not To Be Questioned, 80 S.A.L.J. 187 (1963).

79 "Petitioner, a layman, was undoubtedly unaware that under Illinois law an admission of 'mere' complicity in the murder plot was legally as damaging as an admission of firing of the fatal shots. Illinois v. Escobedo, 28 Ill.2d 41, 190 N.E.2d 825 (1963). The 'guiding hand of counsel' was essential to advise petitioner of his rights in this delicate 
militate even against techniques that impel a suspect to make admissions in awareness of their damaging effect but in ignorance of his privilege not to incriminate himself or in hopelessness that he could in fact exercise that privilege.

Meanwhile, we must do the best we can to insure common-sense application of the Supreme Court rules that now dominate the scene. Thus it would be consonant with the privilege against self-incrimination to leave the police free to hear and act upon volunteered confessions, for as Mr. Justice White has observed, an accused has no "constitutional right not to incriminate himself by making voluntary disclosures." 80 It would also seem sensible not to constrain the police with rules that would mechanically imitate such trial rules as the one that prohibits a prosecutor from even calling a defendant to the stand. ${ }^{81}$ That rule, designed to protect a defendant from adverse inferences that a jury might draw from his refusal to testify, is appropriate to a trial whose outcome might otherwise be determined by such inferences. No comparable rule should be necessary when there is no one but the police to draw adverse inferences from a suspect's refusal to answer questions, for they are powerless to render a verdict. Moreover, he could be readily protected at the trial from such inferences by a rule precluding the prosecution from interpreting silence in the face of police accusation as an adoptive admission. Silence during police interrogation, which is still far from the protective openness and formalities of a court trial, may be attributable to a variety of causes. The accused may not have heard or understood the accusation, or he may have felt there was no need to reply. He may have deemed it prudent to remain silent for fear of reprisals from others. He may simply have been averse to replying under the circumstances of his detention. I would hence welcome a rule that would protect silence at the pretrial stage from invidious interpretation at the trial. ${ }^{82}$

situation. Powell v. Alabama, 287 U.S. 45, 69." Escobedo v. Illinois, 378 U.S. 478, 486 (1964). It is one thing for an accused to make a free choice to speak without first obtaining advice as to the legal effect of his statements. It is quite another for the police deliberately to make it impossible for him to obtain legal advice.

80 Escobedo v. Illinois, 378 U.S. 478, 497 (1964) (White, J., dissenting).

81 No court has allowed the accused to be asked questions without his consent. Case authority is sparse because the rule is so widely assumed. See United States v. Housing Foundation of America, 176 F.2d 665, 666 (3d Cir. 1949); People v. Talle, 111 Cal. App. 2d 650, 245 P.2d 663 (1952); 8 WIGMORE, EvIDENCE \& 2268 (McNaughton rev. 1961).

82 The prosecutor's comment on the defendant's failure to take the stand at trial does not constitute evidence. It "does not relieve the prosecution of its burden of proving every essential element of the crime and the defendant's guilt beyond a reasonable doubt." People v. Modesto, 62 Cal. 2d 436, 449-50, 398 P.2d 753, 761, 42 Cal. Rptr. 417, 435 (1965). In contrast, silence during interrogation would constitute substantive evidence as an adoptive admission, thereby becoming an element in the state's case against the 
It may be worth noting that I find no inconsistency in remaining of the opinion that a judge or prosecutor might fairly comment upon the silence of a defendant at the trial itself to the extent of noting that a jury could draw unfavorable inferences from the defendant's failure to explain or refute evidence when he could reasonably be expected to do so. Such comment would not be evidence and would do no more than make clear to the jury the extent of its freedom in drawing inferences. I have said as much in People v. Modesto, ${ }^{83}$ but the opinion proved to be only the next to the last words in my state. It is now displaced by the famous last words of Griffin $v$. California. ${ }^{84}$

As we reflect on the problem of giving common-sense application to the privilege against self-incrimination at the prearraignment stage, we turn once more to Malloy v. Hogan, which definitively extended the privilege to state trials. It emphasizes the right of an accused "to remain silent unless he chooses to speak in the unfettered exercise of his own will."85 The counterpart of such a privilege at the prearraignment stage could be readily safeguarded if the prosecution were required to lay a foundation for the admission of incriminating statements or confessions by setting forth all the circumstances of the suspect's custody and the details of all interrogations to prove that he was fully aware of his right to remain silent and that the police in no way interfered with "the unfettered exercise of his own will." It would ordinarily be incumbent upon the police who arrested a suspect to inform him meaningfully, as soon as possible thereafter, of his right to remain silent. ${ }^{86}$

accused. Moreover, the prosecution would introduce the accusation to explain the significance of the defendant's silence. Some police officials have read detailed and vivid descriptions of the crime to the defendant together with an accusation that he is the guilty party. If the defendant remains silent and the accusation is introduced as explanation, the jury would have before it a vast amount of hearsay evidence otherwise inadmissible. Even if the jury were charged not to consider this hearsay alone as tending to prove guilt, the possible prejudicial effect is obvious. See People v. Simmons, $28 \mathrm{Cal}$. 2d 699, 716-17, 172 P.2d 18, 27-28 (1946); 2 Wharton, Criminal Evidence $\& 660$ at 1099 (11th ed. 1985); Note, 112 U. PA. L. REv., supra note 74, at 212-13.

8362 Cal. 2d 436, 450-53, 398 P.2d 753, 761-63, 42 Cal. Rptr. 417, $425-27$ (1965).

84380 U.S. 609 (1965).

85378 U.S. 1,8 (1964).

86 Such a rule should not be operative in emergencies, however, as when the police must elicit information from an accused to save life. In such a case in California, we held that the failure of the police to warn the accused of his right to remain silent and his right to counsel did not render inadmissible statements made by the defendant after his victim had disappeared but before her body had been discovered. "They were freely and voluntarily made at a time when the officers were concerned primarily with the possibility of saving [the victim's] life." The paramount interest was to save her life. People v. Modesto, 62 Cal. 2d 436, 446, 398 P.2d 753, 759, 42 Cal. Rptr. 417, 423 (1965).

Such an emergency illustrates the need for flexible rules that take account of interests 
The United States Supreme Court would then be the final arbiter of any constitutional challenge to the sufficiency of proof or to procedures governing the admissibility of evidence. If it determined that disputed parol testimony, such as is common in the coerced confession cases, was so inadequate as to endanger the privilege against selfincrimination, it could require higher standards of proof. Conceivably it could require the police to -make either tape or verbatim stenographic recordings of interrogations and to maintain routine written records of the custody of suspects showing the time and place of interrogation sessions. ${ }^{87}$ Such records would go far to dispel doubts that the police can be relied upon to advise suspects meaningfully of their rights.

On the basis of such records a court could adjudge the validity of police procedures in the light of what happened, instead of in the dark of what might or might not have happened. ${ }^{88}$ It could intelligently determine whether there had been any real violation of the suspect's privilege in the context of the whole record. If it appeared, for example, that he was a criminal lawyer well aware of his constitutional rights, a failure to alert him to his privilege would neither diminish his own awareness thereof nor interfere with "the unfettered exercise of his own will."

Moreover, reliable records would go far to mitigate the evils of secret procedures. They would give some assurance that the normally awesome environment in which a suspect confronts officials of the state would be tempered to induce in him respect for the law rather than dread of its representatives. They would redound to the benefit of the police as well as the suspect by strengthening the foundation for the admissibility in court, in the event of trial, of whatever statements a suspect chose to make of his own will.

An advance toward uniform minimum standards of law enforcement could be expedited by appropriate application of the rules in

superior to those of a suspect in the light of all the circumstances. See the dissenting opinion of Mr. Justice Jackson in Brinegar v. United States, 338 U.S. 160, 183 (1949); McDonald v. United States, 335 U.S. 451, 454 (1948); People v. Smith, 63 Cal. 2d 779, 797-98, 409 P.2d 222, 234-35, 48 Cal. Rptr. 382, 394-95 (1966); People v. Gilbert, 63 Cal. 2d 690, 706-07, 408 P.2d 365, 374-75, 47 Cal. Rptr. 909, 918-19 (1965); People v. Schader, 62 Cal. 2d 716, 724, 401 P.2d 665, 670, 44 Cal. Rptr. 193, 198 (1965). Since the officers acted lawfully, the court had no basis for invoking an exclusionary rule designed to deter unlawful police conduct. In judging whether police conduct has been lawful a court must ask itself the hard question: How otherwise would it have had the police proceed?

87 See Enker \& Elsen, supra note 66, at 85, 87; ALI Model Code of Pre-ARraignment Procedure § 4.09 (Tent. Draft. No. 1, 1966).

88 "If one theme runs through the coerced confession cases, it is that the Court does not know what happened at the police station." Herman, The Supreme Court and Restrictions on Police Interrogation, 25 OHro ST. L.J. 449, 497 (1964). 
Mapp v. Ohio, Malloy v. Hogan, and Gideon v. Wainwright. The Mapp rule, giving force to the fourth amendment's prohibition against unreasonable searches and seizures, could operate to preclude unreasonably long detentions before arraignment $t^{89}$ and still not frustrate reasonable police inquiry for the purpose of determining whether a suspect should be formally charged or released. The square recognition in Malloy $v$. Hogan of a privilege against self-incrimination at the prearraignment stage gives the suspect formidable protection at that stage that could in large measure serve in lieu of the right to counsel. The Gideon rule and its satellites could be amplified to cover a right to counsel no later than the time the suspect should have been arraigned, thereby precluding any maneuver to delay his right to counsel by delaying his arraignment.

This report on the devils of due process in criminal detection and detention leads to a final note on their troublesome Fra Diavolo, the privilege against self-incrimination at trial. There is no need to review here the sorry abuses of justice that led at last to the privilege, ${ }^{90}$ and there is not time to analyze the role of a comparable privilege in congressional investigations or other proceedings as a safeguard either against self-incrimination or against invasions of privacy. ${ }^{91}$ It is timely to recall, however, in relation to the trial, the observation set forth earlier in relation to the pretrial stage, that recent constitutional rules militate against a continuing double standard of the privilege against self-incrimination.

If we illuminate at last the recesses of prearraignment procedures the better to protect any suspect, is he still to keep truth in the dark in the open sessions of a trial, where traditional guarantees of fairness are scrupulously enforced to protect him against accusation that in any event must be proved beyond a reasonable doubt? Will we in time abandon our preoccupation with the privilege, as to the usual crimes not involving beliefs, for an enlarged concern with the overall fairness of criminal procedure? Will we give greater emphasis to the shared interest of the community and of any suspect, guilty or innocent, in fair procedure, and less emphasis to the interest of a guilty suspect in escaping conviction? Would we thereby more effectively counter organized crime without weakening the protection of isolated indi-

89 See Broeder, IVong Sun v. United States: A Study in Faith and Hope, 42 NEB. L. REv. 483, 569-72 (1963).

90 See Sutherland, supra note 72 , at $27-30$.

91 See Meltzer, Invoking the Fifth Amendment-Some Legal and Practical Considerations, 9 BuLL. Aтоміс Scr. 176 (1953); Kalven, Invoking the Fifth Amendment-Some Legal and Impractical Considerations, 9 BurL. ATomic ScI. 181 (1953); Meltzer, Invoking the Fifth Amendment-A Rejoinder, 9 Bull. ATomic Scr. 185 (1953). 
viduals? No one knows what answer will eventually be made to the question suggested earlier: Do we or do we not want a boundless privilege against self-incrimination now that it has doubled itself? That question we leave to the future. ${ }^{92}$

For the present we have enough to do to keep on course with the constitutional rules of criminal procedure. There is no predicting whether they will leave latitude in the law for constructive integration of the studies now under way. It is not too much to hope that the Supreme Court will formulate the rules with a high sense of responsibility for their far-reaching consequences and will make transitions from one case to another that keep the peace between the Constitution and common sense.

As we leave it to its work, we confront the original sin that is the source of most of the troubles we are now having with the devils of due process. It is the deadly sin of sloth, long rampant in our own midst. In the nick of time we can still rouse ourselves to reconstruct the blighted areas of criminal procedure. The problems are fiendish, the work diabolic, but the angels should be on our side.

92 The classic critique of the policies behind the privilege against self-incrimination is still Bentham, Rationaie of Judicial Evidence (1827); see also 8 Wigmore, Evidence $\S 2251$ (McNaughton rev. 1961). 